\title{
Protist community composition in the Pacific sector of the Southern Ocean during austral summer 2010
}

\author{
Christian Wolf $\cdot$ Stephan Frickenhaus · \\ Estelle S. Kilias • Ilka Peeken · Katja Metfies
}

Received: 25 April 2013/Revised: 14 November 2013/Accepted: 7 December 2013/Published online: 21 December 2013

(C) Springer-Verlag Berlin Heidelberg 2013

\begin{abstract}
Knowledge about the protist diversity of the Pacific sector of the Southern Ocean is scarce. We tested the hypothesis that distinct protist community assemblages characterize large-scale water masses. Therefore, we determined the composition and biogeography of late summer protist assemblages along a transect from the coast of New Zealand to the eastern Ross Sea. We used state of the art molecular approaches, such as automated ribosomal intergenic spacer analysis and 454-pyrosequencing, combined with high-performance liquid chromatography pigment analysis to study the protist assemblage. We found distinct biogeographic patterns defined by the environmental conditions in the particular region. Different water masses harbored different microbial communities. In contrast to the Arctic Ocean, picoeukaryotes had minor importance throughout the investigated transect and showed very low contribution south of the Polar Front. Dinoflagellates, Syndiniales, and small stramenopiles were dominating the sequence assemblage in the Subantarctic Zone, whereas the relative abundance of diatoms increased southwards, in the Polar Frontal Zone and Antarctic Zone. South of the Polar Front, most sequences belonged to haptophytes. This study delivers a comprehensive and taxon detailed overview of the protist composition in the investigated area during the austral summer 2010 .
\end{abstract}

C. Wolf $(\bowtie) \cdot$ S. Frickenhaus · E. S. Kilias · I. Peeken

K. Metfies

Alfred Wegener Institute Helmholtz Centre for Polar and Marine Research, Am Handelshafen 12, 27570 Bremerhaven, Germany

e-mail: Christian.Wolf@awi.de

I. Peeken

MARUM, Center for Marine Environmental Sciences, University of Bremen, Leobener Straße, 28359 Bremen, Germany
Keywords Phytoplankton - Eukaryotic diversity · ARISA · Next-generation sequencing · HPLC

\section{Introduction}

Microorganisms are essential for the functioning of marine ecosystems (Azam and Malfatti 2007). Protists are the largest contributors to organic matter in the ocean and constitute an important determinant of the structure and efficiency of Antarctic marine food webs and the flux of particles to the deep ocean (Priddle et al. 1992). However, the extent of their diversity, in particular in polar oceans, remains unclear (Pedros-Alio 2006). The Southern Ocean is predicted to experience changes in temperature, stratification, mixed-layer depth, and acidity, which will affect light climate and nutrient availability (Davidson et al. 2010). These effects will affect the composition and trophodynamics of the Antarctic marine ecosystem (Boyd 2002; Orr et al. 2005; Tortell et al. 2008). Detecting changes in microbial communities will not be possible without information about the current distribution and abundance of protists (Davidson et al. 2010).

The influence of hydrography on microbial communities in polar oceans recently attracted more interest. There are several studies from the Arctic Ocean (Hamilton et al. 2008; Galand et al. 2009; Lovejoy and Potvin 2011) and the Southern Ocean (Diez et al. 2004; Baldwin et al. 2005), addressing the question how hydrography is shaping microbial eukaryotic distribution. Diez et al. (2004), e.g., showed in the Atlantic sector of the Southern Ocean that picoeukaryotic assemblages were characteristic of each water mass. 
Investigations of protist composition and distribution in the Southern Ocean mainly used traditional microscopic (Kopczynska et al. 2007; Chang et al. 2013) or pigment extraction based (Peeken 1997) methods or a combination of both (Ning et al. 1996; Ishikawa et al. 2002; Wright et al. 2009). However, microscopy approaches have difficulties in identifying small cells $(<10 \mu \mathrm{m})$, and thus, this fraction is understudied. Nevertheless, latest studies in the North Sea and the Arctic Ocean report that the smallest size fraction is expected to become more important in marine ecosystems in the future, eventually due to climate change (Daufresne et al. 2009; Li et al. 2009). The introduction of high-performance liquid chromatography (HPLC) into marine biology complemented microscopy and simple biomass investigations of marine phytoplankton. Analyzing group-specific marker pigments, using HPLC analysis, allows determining and distinguishing different size classes within the phytoplankton, including pico- and nanoplankton (Peeken 1997; Wulff and Wangberg 2004; Wright et al. 2009). However, the extraction of pigments from filtered samples followed by HPLC has a low taxonomical resolution. The results critically depend on the pigment matrix and algorithm used for the analysis and the target organisms are limited to autotrophs. Here, molecular tools are advantageous to get high-resolution deep taxonomical information. Molecular techniques deliver detailed information on protist diversity including the small cells that remain unidentified using other techniques.

So far, there are only a few investigations in the Southern Ocean using molecular methods to determine eukaryotes, such as denaturant gradient gel electrophoresis (Diez et al. 2004; Gast et al. 2004) and 18S ribosomal ribonucleic acid (rRNA) gene cloning and sequencing (Diez et al. 2001; Lopez-Garcia et al. 2001). The automated ribosomal intergenic spacer analysis (ARISA) approach provides a quick overview of the diversity, facilitates the comparison of different samples, and is well established for investigations of prokaryotic diversity (Danovaro et al. 2009; Smith et al. 2010). However, to our knowledge, we are the first who successfully applied this approach for diversity studies of protists (Wolf et al. 2013). The majority of published molecular studies concentrated on cloning and sequencing of the $18 \mathrm{~S}$ rRNA gene to elucidate the diversity of protists in the Southern Ocean (Diez et al. 2001; Lopez-Garcia et al. 2001). Bent and Forney (2008) noted that the community diversity may be underestimated due to the limited throughput of this method. During the past decade, 454-pyrosequencing (Margulies et al. 2005) has been established as a high-throughput sequencing methodology and is replacing the Sanger sequencing for comparative metagenomics (Kunin et al. 2010). This next-generation high-throughput sequencing approach allows assessing microbial communities with high resolution, based on sufficient deep taxon sampling (Margulies et al. 2005; Stoeck et al. 2010). The 454-pyrosequencing method has led to the conclusion that the rare biosphere (phylotypes with an abundance $<1 \%$ of total sequences) is more diverse and larger than formerly estimated (Sogin et al. 2006).

The Southern Ocean consists of several large-scale water masses separated by oceanic fronts and is characterized by a large temperature gradient (Orsi et al. 1995). Therefore, it constitutes a good region to test whether distinct protist community assemblages characterize these large-scale water masses and whether the fronts are strong enough to separate these communities.

Therefore, the objective of this study is to determine the composition and biogeography of late austral summer protist assemblages, including the picoplankton fraction (cells $<2 \mu \mathrm{m}$ ), on a north-south transect starting near the New Zealand coast and ending in the eastern Ross Sea. This area consists of very distinct oceanic regions, separated by oceanic fronts (Fig. 1). We combined pigment measurements (HPLC) with state of the art molecular approaches, such as ARISA and 454-pyrosequencing. The pigment and ARISA approach provide an overview of differences in structure and diversity of the entire investigated area. The 454-pyrosequencing of selected representative samples gives detailed information about the taxon composition, dominant representatives, and the distribution of phylotypes in the observed area.

\section{Materials and methods}

\section{Location and sampling}

A total of 31 surface water samples were taken approx. every $100 \mathrm{~km}$ during the $R V$ Polarstern cruise ANT XXVI/ 3 between February 1 and February 12, 2010, in the Pacific sector of the Southern Ocean (Fig. 1) along a north-south transect from the coast of New Zealand to the eastern Ross Sea (within $45.57^{\circ} \mathrm{S}-72.38^{\circ} \mathrm{S}$ latitude and $179.85^{\circ} \mathrm{E}-$ $164.15^{\circ} \mathrm{W}$ longitude). Precise locations and physical conditions are shown in Table 1 . The cruise crossed the major oceanographic fronts and oceanic regions of the Southern Ocean (Fig. 1). The locations of the fronts, including the Subantarctic Front (SAF) and the Polar Front (PF), are taken from Orsi et al. (1995). The zone between the Subtropical Front (STF) and the SAF is stated as the Subantarctic Zone (SAZ). The zone between the SAF and the PF is termed as Polar Frontal Zone (PFZ). The Antarctic Zone (AZ) is arranged south of the PF (Orsi et al. 1995; Pollard et al. 2002).

All water samples were collected using the ship's pumping system (membrane pump) located at the bow at 
Fig. 1 Map of the study area, indicating sampling stations, oceanographic fronts, and oceanic regions. $S T F$

Subtropical Front, $S A F$ Subantarctic Front, $P F$ Polar Front, SAZ Subantarctic Zone, PFZ Polar Frontal Zone, $A Z$ Antarctic Zone. Locations of fronts after Orsi et al. (1995)

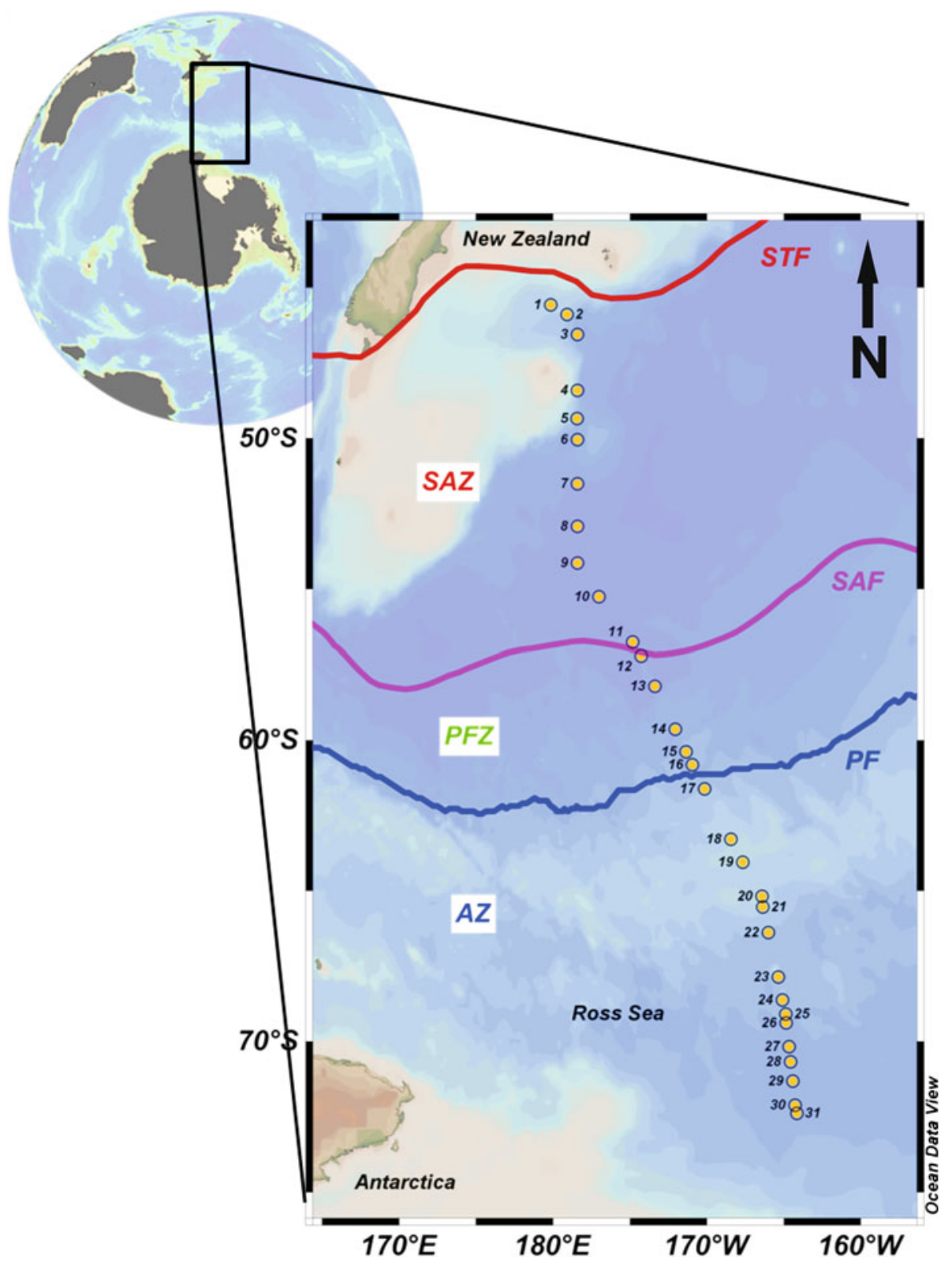

$8 \mathrm{~m}$ below the surface. For the determination of pigments, $4 \mathrm{~L}$ samples were immediately filtered onto 25-mm Whatman GF/F filters and stored at $-80{ }^{\circ} \mathrm{C}$ until further analysis in the laboratory. For molecular analysis, $2 \mathrm{~L}$ samples were immediately filter fractionated onto Isopore Membrane Filters (Millipore, USA) with a pore size of 10,3 , and $0.2 \mu \mathrm{m}$. Filters were stored at $-80{ }^{\circ} \mathrm{C}$ until analysis in the laboratory. The fractionated filtration facilitates the filtration procedure itself and allows a separated amplification in the subsequent PCR step and thus minimizes the danger of under-amplifying small protists, due to the lower gene copy number.
Pigment analysis (HPLC)

Pigment extracts were separated on a Waters HPLC system, equipped with an autosampler (717 plus), pump (600), photo-diode array (2996), a fluorescence detector (2475), and EMPOWER software. For analytical preparation, $50 \mu \mathrm{L}$ internal standard (canthaxanthin) and $1.5 \mathrm{~mL}$ acetone were added to each filter sample and then homogenized for $20 \mathrm{~s}$ in a Precellys ${ }^{\circledR}$ tissue homogenizer. After centrifugation, the supernatant liquid was filtered through a $0.2-\mu \mathrm{m}$ polytetrafluoroethylene (PTFE) filter (Rotilabo) and placed in centrifuge tubes (Eppendorf, Germany). An aliquot $(100 \mu \mathrm{L})$ 
Table 1 Location and physical conditions of surface water samples

\begin{tabular}{|c|c|c|c|c|c|}
\hline Sample & $\begin{array}{l}\text { Longitude } \\
\left({ }^{\circ} \mathrm{W}\right)\end{array}$ & $\begin{array}{l}\text { Latitude } \\
\left({ }^{\circ} \mathrm{S}\right)\end{array}$ & $\begin{array}{l}\text { Temperature } \\
\left({ }^{\circ} \mathrm{C}\right)\end{array}$ & $\begin{array}{l}\text { Salinity } \\
\text { (PSU) }\end{array}$ & $\begin{array}{l}\text { Oceanic } \\
\text { region }\end{array}$ \\
\hline 1 & 179.85 & -45.57 & n.d. & n.d. & SAZ \\
\hline 2 & -179.08 & -45.90 & 16.00 & 34.20 & SAZ \\
\hline 3 & -178.41 & -46.56 & 16.00 & 34.39 & SAZ \\
\hline 4 & -178.41 & -48.41 & 12.07 & 34.09 & SAZ \\
\hline 5 & -178.42 & -49.35 & 12.91 & 34.09 & SAZ \\
\hline 6 & -178.41 & -50.05 & 12.33 & 34.05 & SAZ \\
\hline 7 & -178.41 & -51.52 & 10.88 & 34.00 & SAZ \\
\hline 8 & -178.41 & -52.93 & 12.00 & 34.19 & SAZ \\
\hline 9 & -178.41 & -54.14 & 10.96 & 34.17 & SAZ \\
\hline 10 & -177.01 & -55.25 & 8.75 & 34.12 & SAZ \\
\hline 11 & -174.82 & -56.76 & 6.86 & 33.98 & PFZ \\
\hline 12 & -174.26 & -57.21 & 6.16 & 33.94 & PFZ \\
\hline 13 & -173.37 & -58.22 & 6.12 & 33.95 & PFZ \\
\hline 14 & -172.06 & -59.64 & 4.60 & 33.82 & PFZ \\
\hline 15 & -171.35 & -60.38 & 3.12 & 33.58 & PFZ \\
\hline 16 & -170.93 & -60.82 & 4.64 & 33.84 & PFZ \\
\hline 17 & -170.14 & -61.62 & 2.38 & 33.41 & $\mathrm{AZ}$ \\
\hline 18 & -168.43 & -63.29 & 1.27 & 33.52 & $\mathrm{AZ}$ \\
\hline 19 & -167.66 & -64.05 & 0.70 & 33.54 & $\mathrm{AZ}$ \\
\hline 20 & -166.41 & -65.18 & 0.46 & 33.82 & $\mathrm{AZ}$ \\
\hline 21 & -166.37 & -65.54 & 0.38 & 33.75 & $\mathrm{AZ}$ \\
\hline 22 & -166.01 & -66.39 & 0.25 & 33.81 & $\mathrm{AZ}$ \\
\hline 23 & -165.35 & -67.86 & 0.27 & 33.65 & $\mathrm{AZ}$ \\
\hline 24 & -165.09 & -68.63 & -0.01 & 33.65 & $\mathrm{AZ}$ \\
\hline 25 & -164.88 & -69.09 & -0.14 & 33.55 & $\mathrm{AZ}$ \\
\hline 26 & -164.86 & -69.38 & -0.51 & 33.54 & $\mathrm{AZ}$ \\
\hline 27 & -164.66 & -70.17 & -0.52 & 33.68 & $\mathrm{AZ}$ \\
\hline 28 & -164.57 & -70.67 & -0.57 & 33.81 & $\mathrm{AZ}$ \\
\hline 29 & -164.42 & -71.32 & -0.70 & 33.72 & $\mathrm{AZ}$ \\
\hline 30 & -164.28 & -72.12 & -1.09 & 33.46 & $\mathrm{AZ}$ \\
\hline 31 & -164.15 & -72.38 & -1.32 & 33.35 & $\mathrm{AZ}$ \\
\hline
\end{tabular}

n.d. not determined, SAZ Subantarctic Zone, PFZ Polar Frontal Zone, $A Z$ Antarctic Zone

was transferred to the autosampler $\left(4^{\circ} \mathrm{C}\right)$. Just prior to analysis, the sample was premixed with $1 \mathrm{M}$ ammonium acetate solution in the ratio $1: 1(\mathrm{v} / \mathrm{v})$ in the autosampler and injected onto the HPLC system. The pigments were analyzed by reverse-phase HPLC, using a VARIAN MicrosorbMV3 C8 column $(4.6 \times 100 \mathrm{~mm})$ and HPLC-grade solvents (Merck, Germany). Solvent A consisted of $70 \%$ methanol and $30 \% 1 \mathrm{~mol} \mathrm{~L}^{-1}$ ammonium acetate and solvent B contained $100 \%$ methanol. The gradient was modified after Barlow et al. (1997). Eluting pigments were detected by absorbance $(440 \mathrm{~nm})$ and fluorescence (Ex: $410 \mathrm{~nm}, \mathrm{Em}$ : $>600 \mathrm{~nm}$ ). The following pigments were analyzed (chlorophyll $c 1+2, c 3$ and $b$, peridinin, fucoxanthin, neoxanthin, violaxanthin, 19-butanoyl- and 19-hexanoyl-oxy-fucoxanthin, alloxanthin, and gyroxanthin. Pigments were identified by comparing their retention times with those of pure standards and algal extracts. Additional confirmation for each pigment was done with representative samples using on-line diode array absorbance spectra between 390 and $750 \mathrm{~nm}$. Pigment concentrations were quantified based on peak areas of external standards, which were spectrophotometrically calibrated using extinction coefficients published by Bidigare (1991) and Jeffrey et al. (1997). For correction of experimental losses and volume changes, the concentrations of the pigments were normalized to the internal standard canthaxanthin. Phytoplankton group composition was calculated applying the CHEMTAX program and input ratios (omitting lutein and prasinoxanthin) of Wright et al. (2010). The relative contribution to total biomass was based on their CHEMTAX-derived chlorophyll $a$ concentration.

\section{DNA extraction}

The DNA was extracted with the E.Z.N.A.TM SP Plant DNA Kit (Omega Bio-Tek, USA). The filters were first incubated with lysis buffer for $10 \mathrm{~min}$ at $65^{\circ} \mathrm{C}$. All further steps were performed as described in the manufacturer's instructions. At the end, the DNA was eluted in $60 \mu \mathrm{L}$ of elution buffer and the extracts were stored at $-20^{\circ} \mathrm{C}$ until further analysis. DNA concentration was measured with a NanoDrop 1000 (Thermo Fisher Scientific, USA) (average DNA concentration: $24 \mathrm{ng} \mu \mathrm{L}^{-1}$ ).

\section{PCR amplification, ARISA}

An equal volume of extracted DNA of each size fraction (>10, 3-10, and 0.2-3 $\mu \mathrm{m}$ ) from each sample was pooled. The pooling was done before the amplification, because this approach is based on the presence/absence of fragments, and thus, it is less prone to amplification biases. The ITS1 (internal transcribed spacer) region was amplified in triplicates with the primers $1528 \mathrm{~F}$ (5'-GTA GGT GAA CCT GCA GAA GGA TCA-3') [modified after Medlin et al. (1988)] and ITS2 (White et al. 1990). The 1528F primer was labeled with the dye 6-FAM (6-Carboxyfluorescein). The PCR mixtures contained $1 \mu \mathrm{L}$ of DNA extract, $1 \times$ HotMaster Taq Buffer containing $2.5 \mathrm{mmol} \mathrm{L}^{-1} \mathrm{Mg}^{2+}$ (5 Prime, USA), $0.8 \mathrm{mmol} \mathrm{L}^{-1}$ deoxynucleoside triphosphate (dNTP) mix (Eppendorf, Germany), $0.2 \mu \mathrm{mol} \mathrm{L}^{-1}$ of each primer, and $0.4 \mathrm{U}$ of HotMaster Taq DNA polymerase (5 Prime, USA) in a final volume of $20 \mu \mathrm{L}$. Reactions were carried out in a Mastercycler (Eppendorf, Germany) under the following conditions: an initial denaturation at $94{ }^{\circ} \mathrm{C}$ for 3 min, 35 cycles of denaturation at $94{ }^{\circ} \mathrm{C}$ for $45 \mathrm{~s}$, annealing at $55{ }^{\circ} \mathrm{C}$ for $1 \mathrm{~min}$, extension at $72{ }^{\circ} \mathrm{C}$ for $3 \mathrm{~min}$, and a final extension at $72{ }^{\circ} \mathrm{C}$ for $10 \mathrm{~min}$. PCR fragments were 
separated by capillary electrophoresis on an ABI Prism 310 Genetic Analyzer (Applied Biosystems, USA).

PCR amplification, 454-pyrosequencing

Six samples were chosen for 454-pyrosequencing based on the pigments, ARISA analysis, and their location (samples 6 and 8 for the SAZ, sample 16 for the PFZ, and samples 22,25 , and 26 for the AZ). For each size fraction of a sample, we amplified $\sim 670 \mathrm{bp}$ fragments of the 18S rRNA gene, containing the highly variable V4-region, using the primer set 528F (5'-GCG GTA ATT CCA GCT CCA A-3') and 1055R (5'-ACG GCC ATG CAC CAC CAC CCA T-3') [modified after Elwood et al. (1985)]. The PCR mixtures were composed as described previously for ARISA. Reaction conditions were as follows: an initial denaturation at $94{ }^{\circ} \mathrm{C}$ for $3 \mathrm{~min}, 30$ cycles of denaturation at $94{ }^{\circ} \mathrm{C}$ for $45 \mathrm{~s}$, annealing at $59^{\circ} \mathrm{C}$ for $1 \mathrm{~min}$, extension at $72{ }^{\circ} \mathrm{C}$ for $3 \mathrm{~min}$, and a final extension at $72{ }^{\circ} \mathrm{C}$ for $10 \mathrm{~min}$. For each sample, an equal volume of PCR of each size fraction was pooled and purified with the MinElute PCR purification kit (Qiagen, Germany). The fractionated amplification minimizes the danger of under-amplifying small protists (e.g., picoeukaryotes), due to the lower gene copy number. Pyrosequencing was performed on a Genome Sequencer FLX system (Roche, Germany) by GATC Biotech AG (Germany).

\section{Data analysis, ARISA}

Electropherograms were analyzed using the GeneMapper Software v4.0 (Applied Biosystems, USA). Peaks with a size smaller than $50 \mathrm{bp}$ (corresponding to primer and primer-dimer peaks) were removed from the data set. To remove the background noise and to get sample-by-binnedoperational-taxonomic-unit tables, the data were binned using the binning scripts, according to Ramette (2009), for R (R Development Core Team 2008). The resulting sample-by-binned-operational-taxonomic-unit tables were transformed into the presence/absence matrices for further statistical analysis.

\section{Data analysis, 454-pyrosequencing}

Recently, the use of denoising steps was questioned (Comeau et al. 2013). Denoising can transform final sequences, inconsistent with the spectrum of errors (Gaspar and Thomas 2013). We omitted the denoising step and raw sequence reads were processed via our own pipeline to obtain highquality reads. The forward primer $528 \mathrm{~F}$, used for the sequencing, attaches approx. $25 \mathrm{bp}$ upstream of the V4 region, which has in general a length of approx. $230 \mathrm{bp}$ (Nickrent and Sargent 1991). Reads with a length under
$300 \mathrm{bp}$ were excluded from further analysis to assure the including of the complete hypervariable V4 region in the analysis and to get rid of the short reads. Unusually long reads that were greater than the expected amplicon size $(>670 \mathrm{bp}$ ) and reads with more than one uncertain base (N) were removed. Remaining reads were checked for chimeric sequences with the software UCHIME 4.2 (Edgar et al. 2011), and all reads considered being chimeric were excluded from further analysis. The high-quality reads of all samples were clustered into operational taxonomic units (OTUs) at the $97 \%$ similarity level using the software Lasergene 10 (DNASTAR, USA). Subsequently, reads not starting with the forward primer were manually removed. Consensus sequences of each OTU were generated, which reduced the amount of sequences to operate with and attenuated the influence of sequencing errors and uncertain bases. The $97 \%$ similarity level has shown to be the most suitable to reproduce original eukaryotic diversity (Behnke et al. 2011) and has also the effect of bracing most of the sequencing errors (Kunin et al. 2010). Furthermore, known intragenomic SSU polymorphism levels can range to $2.9 \%$ in dinoflagellate species (Miranda et al. 2012). OTUs comprised of only one sequence (singletons) were removed. The consensus sequences were aligned using the software HMMER 2.3.2 (Eddy 2011). Subsequently, taxonomical affiliation was determined by placing the consensus sequences into a reference tree, containing about 1,200 highquality sequences of Eukarya from the SILVA reference database (SSU Ref 108), using the software pplacer 1.0 (Matsen et al. 2010). The compiled reference database is available on request in ARB format. OTUs assigned to fungi and metazoans were excluded from further analysis. Rarefaction curves were computed using the freeware program Analytic Rarefaction 1.3. For statistical analysis, all samples were subsampled to 9,865 sequences and a presence/absence matrix of OTUs was generated. The data set generated in this study has been deposited at GenBank's Short Read Archive (SRA) under Accession No. SRA056811.

\section{Statistics}

All statistical analyses were performed with $\mathrm{R}$ (R Development Core Team 2008). Sample 1 was excluded from the statistical analysis, because there were no environmental parameters available. Environmental conditions showed no normal distribution (Shapiro-Wilk test), and therefore, the Mann-Whitney $U$ test was performed to test the significance of differences between the three oceanic regions.

For statistical evaluation of the pigment data, only the specific diagnostic marker pigments (chlorophyll $b$, peridinin, neoxanthin, violaxanthin, alloxanthin, and gyroxanthin) were included. Distances between the samples were 
Fig. 2 Total Chl

$a$ concentration based on CHEMTAX identification of the various algae classes. Locations of oceanographic fronts (dotted lines) and regions are indicated. $S A F$ Subantarctic Front, $P F$ Polar Front, SAZ Subantarctic Zone, PFZ Polar Frontal Zone, $A Z$ Antarctic Zone

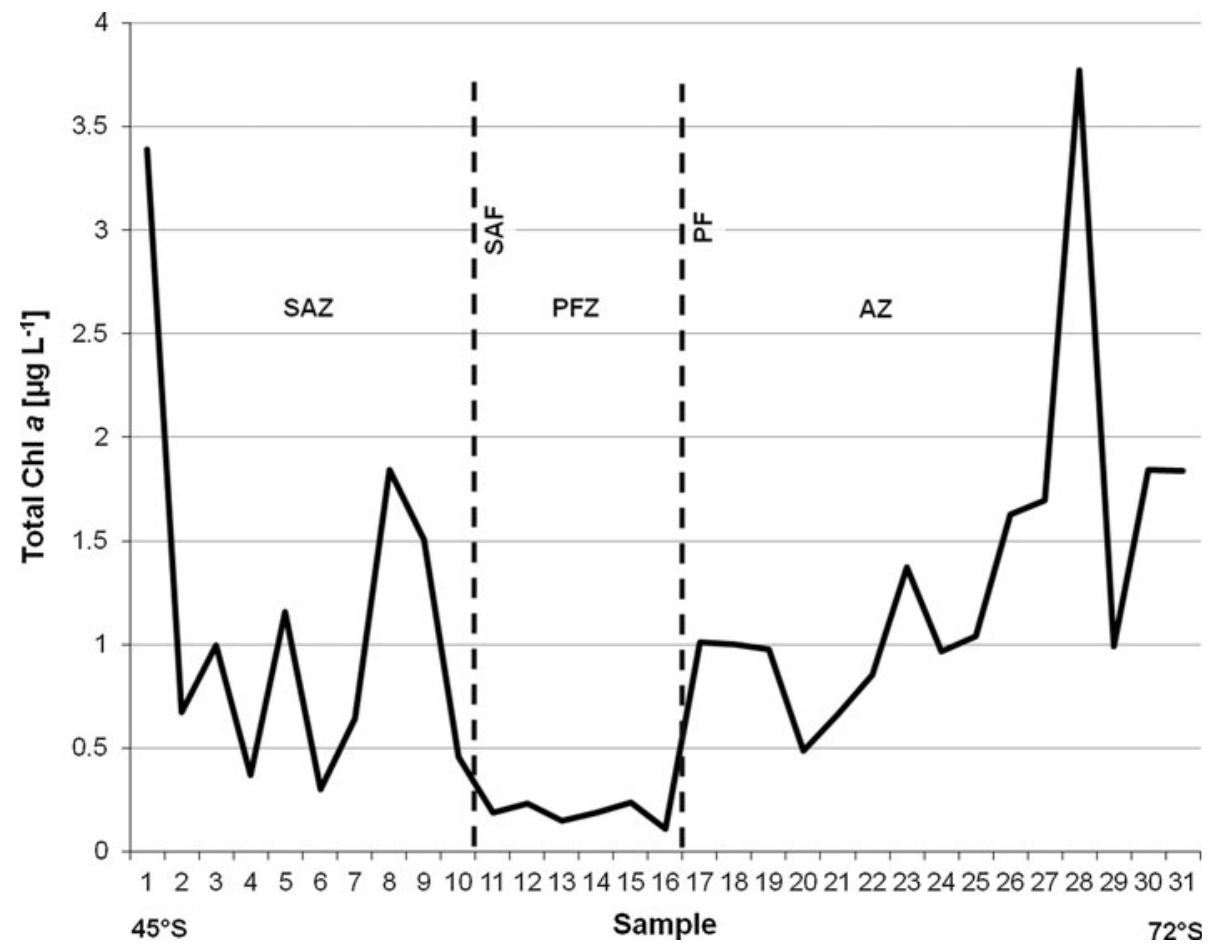

calculated using the Bray Curtis index (pigments), the Jaccard index (ARISA, 454-pyrosequencing), and the Euclidean distance (environmental conditions) implemented in the $\mathrm{R}$ package vegan (Oksanen et al. 2012), which was also used in the following steps. The clustering of the samples was determined using the hclust function. The resulting clusters were tested for significant differences using the ANOSIM test. Multidimensional scaling (MDS) plots (maximum random starts of 1,000) were computed. The correlation between the distance matrices and the environmental distance matrix (temperature and salinity) was tested with a Mantel test $(10,000$ permutations), implemented in the $\mathrm{R}$ package ade4 (Dray and Dufour 2007). To assess the significance of the environmental variables, a permutation test was performed, using the envfit function ( $\mathrm{R}$ package vegan). A PCA with the environmental parameters was performed ( $\mathrm{R}$ package ade4).

\section{Results}

\section{Environmental conditions}

Along the investigated transect, we crossed two major fronts, the SAF and the PF (Fig. 1). The three oceanic regions showed different environmental conditions, especially in terms of temperature (Table 1). The average surface water temperature in the $\mathrm{SAZ}$ was $12.4 \pm 2.4^{\circ} \mathrm{C}$ and the average salinity was $34.1 \pm 0.1 \mathrm{psu}$. The PFZ showed an average surface water temperature of $5.3 \pm 1.4{ }^{\circ} \mathrm{C}$ and an average salinity of $33.9 \pm 0.2 \mathrm{psu}$. The average surface water temperature in the $\mathrm{AZ}$ was $0.1 \pm 1{ }^{\circ} \mathrm{C}$ and the average salinity was $33.6 \pm 0.2 \mathrm{psu}$. No sea ice was present throughout the entire transect. The statistical analysis showed that temperature and salinity differed significantly (all $p$ values $<0.05$ ) between the three oceanic regions.

Structure overview

We used a combination of HPLC and ARISA to identify the structure of the protist assemblages in the investigated area. The observed patterns enabled us to select representative samples for subsequent 454-pyrosequencing.

\section{HPLC}

Total Chl $a$ concentrations showed a pattern corresponding with the oceanographic fronts and oceanic regions (Fig. 2). The concentrations ranged between 0.11 and $3.77 \mu \mathrm{g} \mathrm{L}^{-1}$ and were mostly greater than $0.5 \mu \mathrm{g} \mathrm{L}^{-1}$. In the SAZ, Chl $a$ concentrations were highly variable, ranging from 0.3 to $3.39 \mu \mathrm{g} \mathrm{L}^{-1}$. The average concentration in the PFZ was $0.18 \pm 0.06 \mu \mathrm{g} \mathrm{L}^{-1}$. The AZ also showed highly variable Chl $a$ concentrations, ranging from 0.49 to $3.77 \mu \mathrm{g} \mathrm{L}^{-1}$. The highest concentrations were measured as 3.39 and $3.77 \mu \mathrm{g} \mathrm{L}^{-1}$ in samples 1 and 28 , respectively. The concentrations were lowest in the PFZ with values not exceeding $0.24 \mu \mathrm{g} \mathrm{L}^{-1}$. The ordination analysis based on the pigment profiles (Fig. 3a) clustered the samples in three 


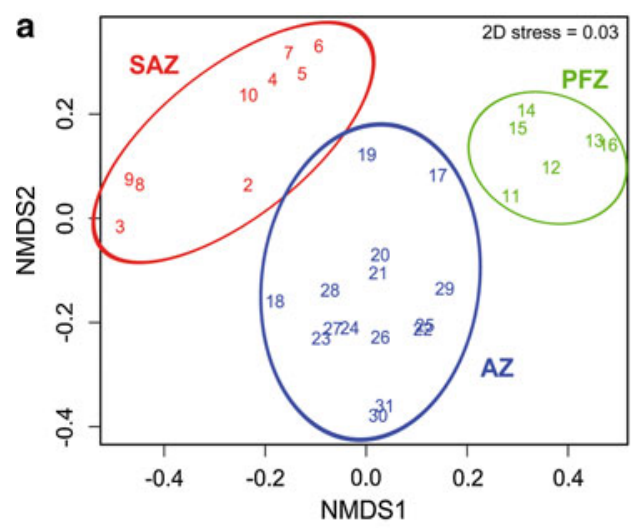

C

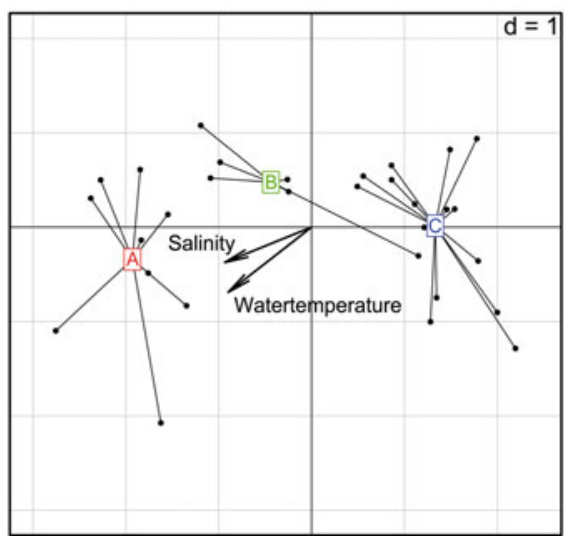

Fig. 3 Multivariate analysis. a MDS plot based on Bray Curtis distances of 30 samples gained via pigment profiles. Ellipses are indicating three groups, Subantarctic Zone (SAZ) in red, Polar Frontal Zone (PFZ) in green, and Antarctic Zone (AZ) in blue. b MDS plot based on Jaccard distances of 30 samples gained via ARISA profiles. Ellipses are indicating three groups, Subantarctic Zone (SAZ) in red, Polar Frontal Zone (PFZ) in green, and Antarctic Zone (AZ) in blue. c PCA of environmental conditions with plotted groups $(A=\mathrm{SAZ}$,

groups according to the two main fronts, the SAF and the PF (Fig. 1). The three groups suit very well to the oceanic regions, the SAZ, the PFZ, and the AZ. The three groups showed significantly different pigment profiles (ANOSIM, $R=0.856, p=0.001$ ). The pigment profiles distances were significantly correlated with the distances of the environmental condition profiles (Mantel test, $r=0.548$, $p=0.0001$ ). The permutation test (envfit) showed that temperature $\left(r^{2}=0.73, \quad p=0.001\right)$ and salinity $\left(r^{2}=0.56, p=0.001\right)$ were relevant for explaining the pattern.

\section{ARISA}

The fragment length analysis of the ITS1 region of all 31 surface water samples resulted in 102 different fragments with a length of 50 to $432 \mathrm{bp}$, of which 15 occurred in only one of the samples (unique fragments). On average, the number of
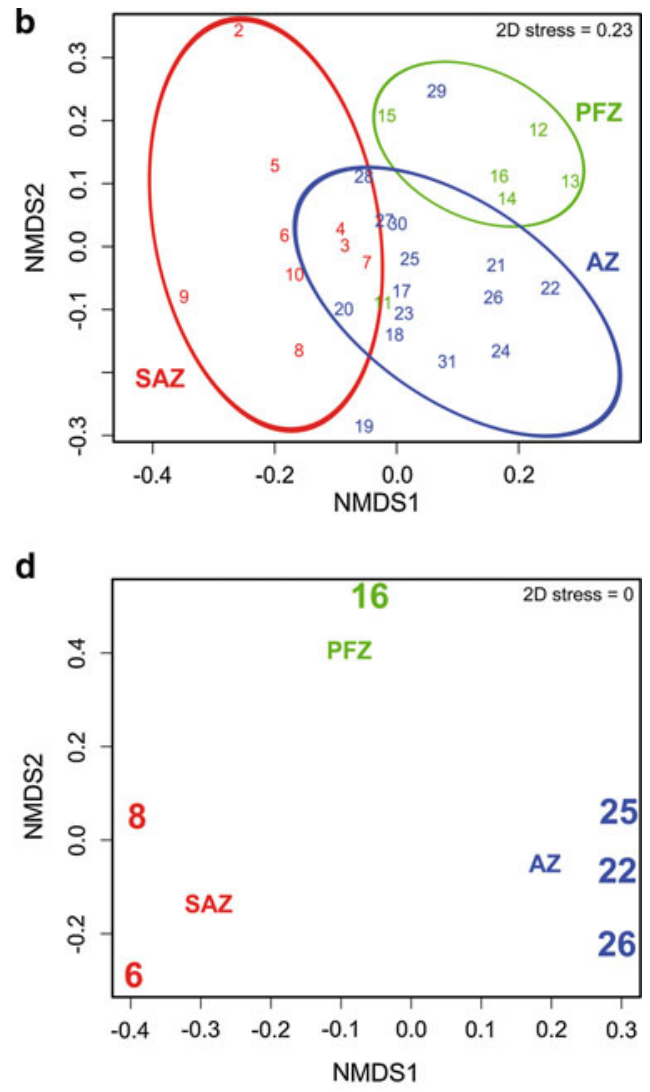

$B=\mathrm{PFZ}, C=\mathrm{AZ}$ ). Both axes are explaining $96 \%$ of the variance (PC1: $78 \%$, PC2: $18 \%$ ). Group A shows the highest, group B intermediate, and group $\mathrm{C}$ the lowest temperature and salinity values. d MDS plot based on Jaccard distances of six samples gained via OTU profiles (454-pyrosequencing). Three groups are indicated as follows: Subantarctic Zone (SAZ) in red, Polar Frontal Zone (PFZ) in green, and Antarctic Zone (AZ) in blue

fragments of each sample was 39 and ranged between 27 (sample 31) and 52 (sample 2). The ordination analysis based on the ARISA profiles (Fig. 3b) clustered the samples in the same three groups as the pigment profiles. The three groups showed significantly different ARISA profiles (ANOSIM, $R=0.348, p=0.001$ ). The ARISA profiles distances were significantly correlated with the distances of the environmental condition profiles (Mantel test, $r=0.187, p=0.008$ ). The permutation test (envfit) showed that temperature $\left(r^{2}=0.41, p=0.001\right)$ and salinity $\left(r^{2}=0.3, p=0.009\right)$ were relevant for explaining the pattern.

The PCA (Fig. 3c) of the environmental conditions confirmed the three groups found via HPLC and ARISA. The two axes were explaining $96 \%$ of the total variance. The three groups were characterized by different temperature and salinity regimes. Temperature and salinity values decreased from group A to $\mathrm{C}$, as indicated by the corresponding axis. 


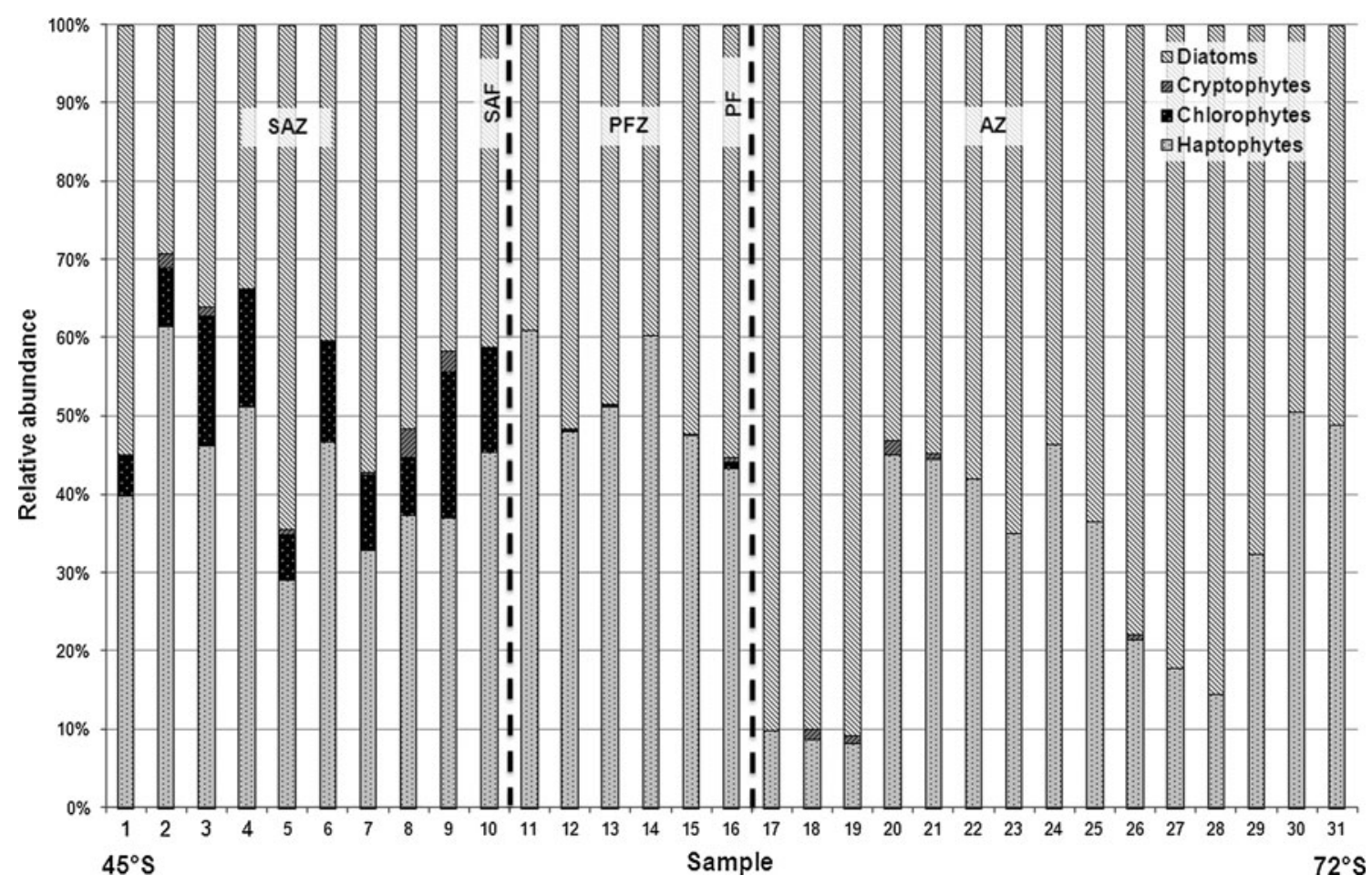

Fig. 4 Contribution of phytoplankton groups (diatoms, cryptophytes, chlorophytes, and haptophytes) to total Chl $a$ based on CHEMTAX analysis. Locations of oceanographic fronts (dotted lines) and regions

\section{4-Pyrosequencing}

The ordination analysis based on the OTU profiles (Fig. 3d) clustered the six samples in the same three groups as the pigment and ARISA profiles. The three groups showed significantly different OTU profiles (ANOSIM, $R=1$, $p=0.017$ ). The OTU profiles distances were significantly correlated with the distances of the environmental condition profiles (Mantel test, $r=0.845, p=0.016$ ). The permutation test (envfit) showed that temperature $\left(r^{2}=0.99\right.$, $p=0.012$ ) was relevant for explaining the pattern.

\section{Community composition}

The CHEMTAX analysis of the measured pigments revealed that chlorophytes (chlorophytes and prasinophytes were merged) only occur noteworthily north of the SAF (Fig. 4). There they accounted for 5-18.5\%. In the PFZ, chlorophytes only contributed up to $0.7 \%$, and south of the $\mathrm{PF}$, they were absent. Cryptophytes only appeared in some samples with low relative abundances (0.01-3.67\%). North of the PF, haptophytes (haptophytes-H and haptophytes-L were merged) showed a relative constant contribution with over $29 \%$ in all samples. The highest relative abundance $(\sim 60 \%)$ occurred in samples 2 (SAZ), 11 and 14 (PFZ). South of the PF, the contribution of haptophytes are indicated. SAF Subantarctic Front, $P F$ Polar Front, $S A Z$ Subantarctic Zone, $P F Z$ Polar Frontal Zone, $A Z$ Antarctic Zone

ranged from $8.2 \%$ (sample 19) to $50.5 \%$ (sample 30 ). Diatoms (diatoms-A and diatoms-B were merged) were the dominating group south of the PF with a contribution of $49.5 \%$ (sample 30) to $90.8 \%$ (sample 19). North of the PF, they accounted for $29.3 \%$ (sample 2) to $64.5 \%$ (sample 5). Dinoflagellates were omitted, because they were always contributing less than $1 \%$.

Six samples were chosen for 454-pyrosequencing based on the pigments and ARISA analysis and their location (samples 6 and 8 for the SAZ, sample 16 for the PFZ, and samples 22, 25, and 26 for the AZ).

The summary of recovered 454-pyrosequencing reads and the quality filtering can be seen in Table 2. A total of 300,582 sequence reads were retrieved from 454-pyrosequencing, of which $76.4 \%$ had an acceptable length (300-670 bp). After the quality filtering, $58 \%$ of the total reads were left over for analysis. The number of analyzed reads ranged between roughly 10,000 (sample 16) to over 50,000 (sample 22 and 26). Subsequent to the clustering, 3,841 different OTUs were generated. The number of OTUs (Table 2) for each sample ranged between 630 (sample 16) and 1,695 (sample 22), at which only $0.4 \%$ (sample 22) to $2.4 \%$ (sample 16) were abundant (number of reads $\geq 1 \%$ of total reads).

Rarefaction curves (not shown) revealed that none of the samples was sampled to saturation. However, the trend of 
Table 2 Summary of recovered 454-pyrosequencing reads, quality filtering, and number of operational taxonomic units (OTUs) a Reads with a minimum length of $300 \mathrm{bp}$ and a maximum length of $670 \mathrm{bp}$

b Abundant OTU $=$ number of reads $\geq 1 \%$ of total reads, otherwise it is rare

\begin{tabular}{|c|c|c|c|c|c|c|}
\hline & \multicolumn{6}{|l|}{ Sample } \\
\hline & \multicolumn{2}{|l|}{ SAZ } & \multirow{2}{*}{$\begin{array}{l}\text { PFZ } \\
16\end{array}$} & \multicolumn{3}{|l|}{$\mathrm{AZ}$} \\
\hline & 6 & 8 & & 22 & 25 & 26 \\
\hline Total 454-reads & 25,377 & 29,383 & 34,029 & 86,001 & 45,772 & 80,020 \\
\hline Average length (bp) & 366 & 337 & 345 & 364 & 333 & 380 \\
\hline Acceptable length $^{\mathrm{a}}$ & 19,186 & 21,593 & 25,578 & 65,689 & 33,356 & 64,114 \\
\hline \multicolumn{7}{|l|}{ Quality filtering } \\
\hline More than one $\mathrm{N}$ & 146 & 228 & 204 & 407 & 107 & 427 \\
\hline Chimeras & 570 & 407 & 253 & 1,422 & 990 & 1,967 \\
\hline Incorrect forward primer & 117 & 145 & 357 & 312 & 322 & 327 \\
\hline Singletons & 2,078 & 1,309 & 653 & 5,361 & 3,498 & 3,723 \\
\hline Non-target organisms & 1,170 & 3,039 & 14,246 & 4,444 & 4,023 & 2,863 \\
\hline Total filtered reads & 15,105 & 16,465 & 9,865 & 53,743 & 24,416 & 54,807 \\
\hline OTUs (97\% similarity) & 1,105 & 1,084 & 630 & 1,695 & 1,308 & 1,592 \\
\hline Abundant OTUs ${ }^{\mathrm{b}}$ & 16 & 14 & 15 & 7 & 13 & 8 \\
\hline Rare OTUs ${ }^{\mathrm{b}}$ & 1,089 & 1,070 & 615 & 1,688 & 1,295 & 1,584 \\
\hline
\end{tabular}

the curves suggests that sample 16 harbored the lowest diversity.

The placement of all OTUs resulted in an assignment of all reads to major protist groups, and the relative abundance of sequences assigned to these groups was calculated (Fig. 5). The read abundance of haptophytes increased southwards from $14.3 \%$ on average in the SAZ to $28.2 \%$ in the PFZ and to $39.5 \%$ on average in the AZ. In the AZ, they were dominating the sequence assemblage. Chlorophytes were only occurring in appreciable amounts in the SAZ, where they constituted up to $6.4 \%$ of the reads. Pelagophytes showed their maximum read abundance in the PFZ with $4.1 \%$. The read abundance of diatoms increased southwards from 2.7 to $3.8 \%$ in the SAZ to $12.9 \%$ in the PFZ and to $10.1-24.3 \%$ in the AZ. Labyrinthulids only occurred in significant amounts in the SAZ, where they accounted for 5-13.8 \% of all reads. The group of marine stramenopiles (MAST) showed the highest read abundance in the PFZ and in sample 25 with $5.2 \%$ and $5.1 \%$, respectively. Dinoflagellates were dominating the sequence assemblage in the SAZ, where they accounted for $31.6-58 \%$ of the reads. Their read abundance was lower south of the SAF (23.8 \% in the PFZ and 30-37.3 \% in the AZ). North of the PF, Syndiniales accounted for 9.2-16.1\% of the reads, whereas south of the PF, they only accounted for $0.9-1.7 \%$. Ciliates showed a southwards increase in sequence abundance from $0.5 \%$ on average in the SAZ to $2.7 \%$ in the PFZ and to $3.7 \%$ on average in the AZ.

Of the 3,841 different OTUs found in all samples, 36 were abundant (read abundance $>1 \%$ of total reads) in at least one sample. These 36 OTUs were present in at least two regions and even 23 were present in all three regions.

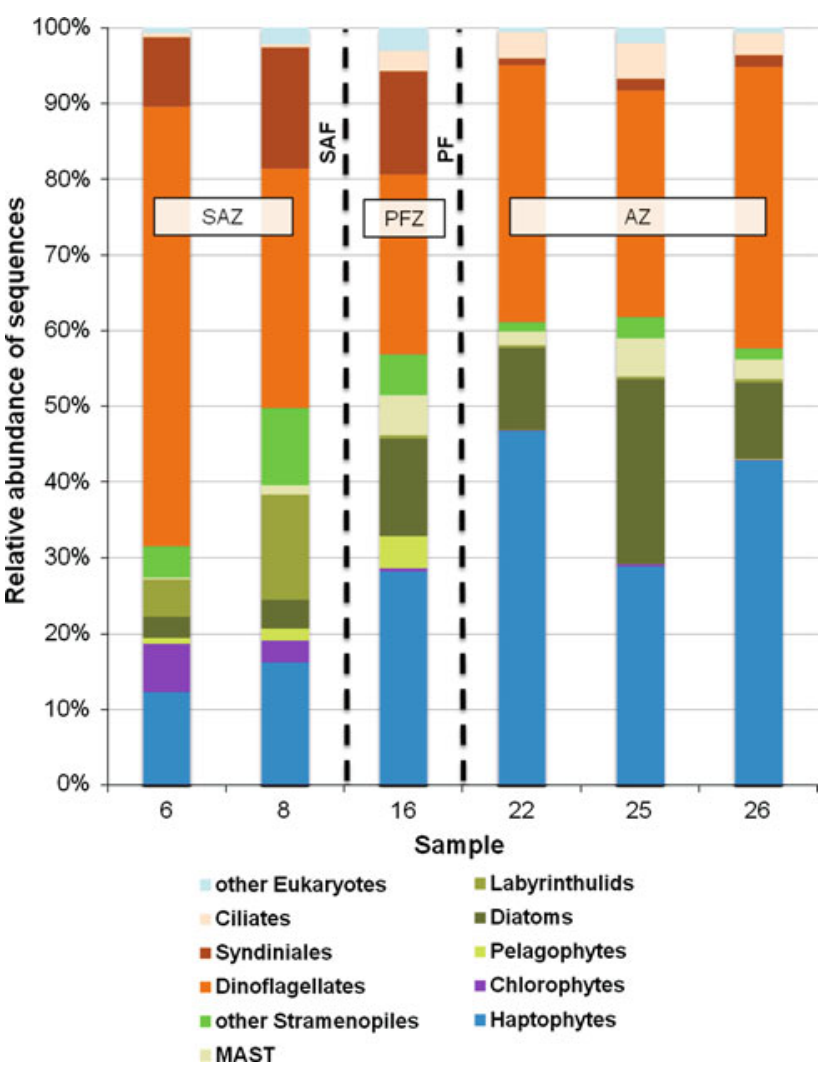

Fig. 5 Relative abundance of sequence reads, gained via 454-pyrosequencing, assigned to major taxonomic groups. Locations of oceanographic fronts are indicated (dashed lines). SAF Subantarctic Front, $P F$ Polar Front, SAZ Subantarctic Zone, PFZ Polar Frontal Zone, $A Z$ Antarctic Zone

The relative sequence read abundance of the abundant OTUs in all six samples is presented in a color-coded matrix (Fig. 6). We generally did not classify the OTUs 
Fig. 6 Color-coded matrix plot, illustrating the relative read abundance of the 36 abundant OTUs (abundance $\geq 1 \%$, at least in one sample) in the six sequenced samples. White boxes indicate the absence of the respective OTU. SAZ Subantarctic Zone, $P F Z$ Polar Frontal Zone, $A Z$ Antarctic Zone

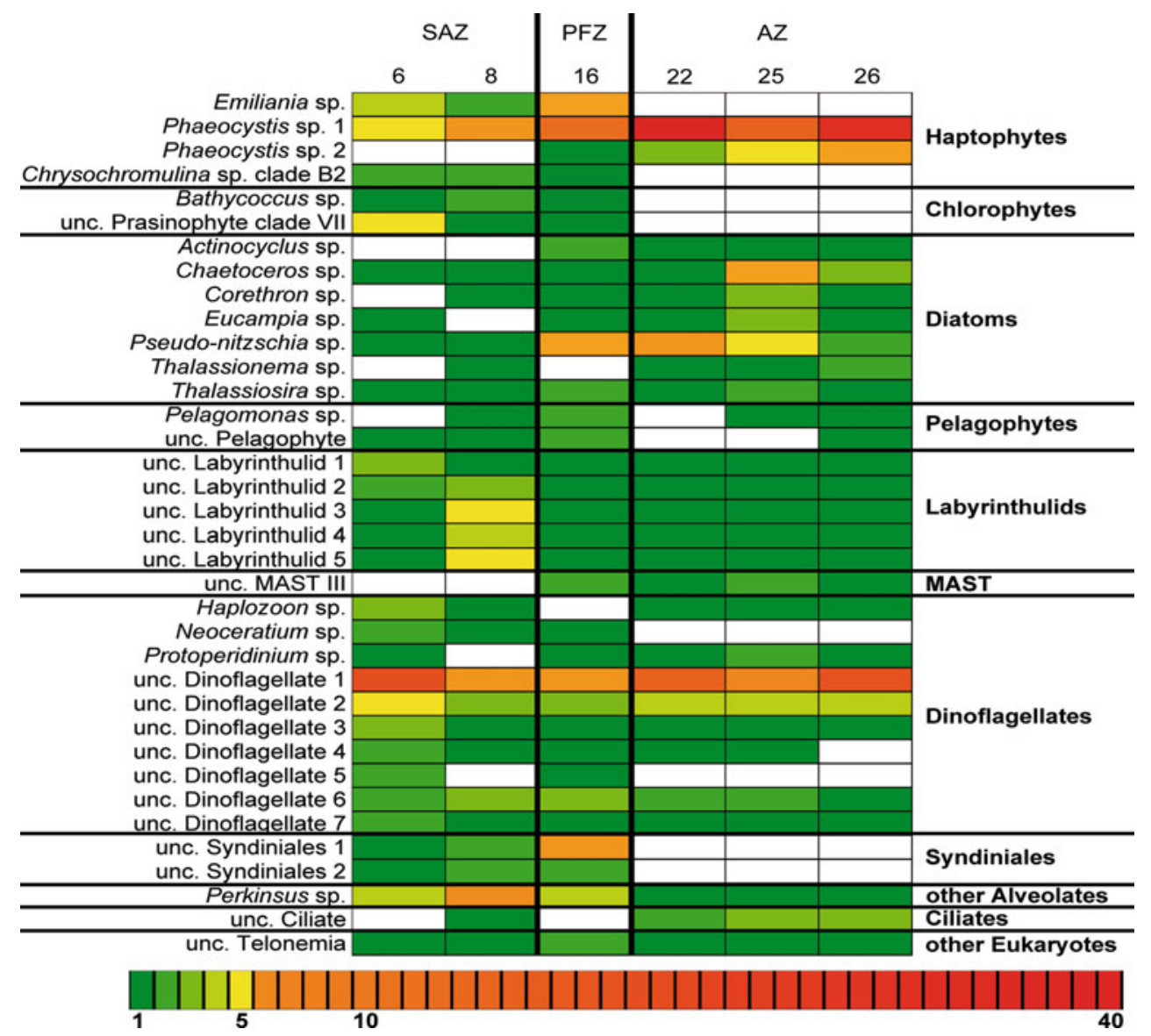

beyond the genus level, because the length of only $\sim 500-600$ bp is decreasing the robustness of the phylogenetic annotation. Emiliania sp. and Chrysochromulina sp. clade B2 (Edvardsen et al. 2011) sequences, belonging to coccolithophores, only occurred north of the PF. Phaeocystis sp. 1 was detected in all samples, whereas the read abundance was increasing southwards and was most dominant in the AZ with 19.2-40.4\% of all sequences. Sequences assigned to the Phaeocystis sp. 2 OTU were only occurring south of the SAF. Reads related to chlorophytes [Bathycoccus sp. and unc. Prasinophyte clade VII (Guillou et al. 2004)] were only present north of the PF. In general, the read abundance of diatoms (Actinocyclus sp., Chaetoceros sp., Corethron sp., Eucampia sp., Pseudonitzschia sp., Thalassionema sp. and Thalassiosira sp.) was increasing southwards. Almost all diatom OTUs were rare (read abundance $<1 \%$ of total reads) or absent in the SAZ. The OTUs belonging to pelagophytes (Pelagomonas sp. and unc. Pelagophyte) showed their highest abundance in the PFZ. Labyrinthulids (unc. Labyrinthulid 1-5) were only abundant in the SAZ. The unc. MAST OTU only occurred in the PFZ and the AZ. Besides haptophytes, sequences related to dinoflagellates were the numerically dominant group in our data set across the entire transect. The most dominant OTU was the unc. Dinoflagellate 1, which accounted for up to $23.5 \%$ of the sequences. Most of the dinoflagellate OTUs showed their highest read abundance in the SAZ and the PFZ. Some were absent in the AZ. All seven unc. Dinoflagellate OTUs could not be assigned to a family (Incertae sedis). Syndiniales (unc. Syndiniales 1-2, both Dino-Group II) only occurred north of the PF. The OTU assigned to Perkinsus sp., which belongs to the alveolates, showed the highest abundance north of the PF with up to $9.89 \%$ of the sequences. The read abundance of the Ciliate 1 OTU was highest south of the PF. The unc. Telonemia 1 OTU was rare, except in the PFZ.

\section{Discussion}

Structure overview

With the combination of HPLC, ARISA, and 454-pyrosequencing, we gained an overview of the protist distribution and assemblage structure across the entire transect (from the coast of New Zealand to the eastern Ross Sea) during austral summer 2010. The pattern, found here, is concatenated with the environmental gradients and the different 
communities are separated by the oceanic fronts in this area.

The range of the Chl $a$ concentrations measured in our study coincides with values generally found in Antarctic surface waters (Ishikawa et al. 2002; Wright et al. 2009; Kozlowski et al. 2011). In the southern Indian Ocean, Chl $a$ concentrations in late spring vary between 0.2 and $0.4 \mu \mathrm{g} \mathrm{L}^{-1}$ but in areas influenced by Southern Ocean waters, they can increase to $1.4 \mu \mathrm{g} \mathrm{L}^{-1}$ (Schlüter et al. 2011). In general, higher Chl $a$ concentrations are often connected with high abundances of large diatoms (Detmer and Bathmann 1997; Ishikawa et al. 2002). In our study, higher Chl $a$ concentrations were also found in samples that had higher proportion of diatoms. The highest Chl $a$ concentration of $3.77 \mu \mathrm{g} \mathrm{L}^{-1}$ was observed in sample 28 , where pigments showed a diatom proportion of $85 \%$. The scattered Chl $a$ peaks measured here illustrate the patchiness of phytoplankton blooms in the Southern Ocean.

Despite the generally high nutrient concentrations in waters of the Southern Ocean, micronutrient availability, especially iron, is considered responsible for the widespread low phytoplankton biomass and patchiness occurrence of blooms (high nutrient, low chlorophyll regions) (Martin et al. 1990; Debaar et al. 1995; Banse 1996). Areas with higher Chl $a$ concentrations might be influenced by micronutrient supply via melting icebergs or dust from the atmosphere; especially in the PFZ, Chl $a$ concentrations are generally low (Banse 1996). This fits to our observation of the lowest biomass and Chl $a$ concentration in that area.

In temperate, subtropical, and tropical open ocean waters of the Atlantic and Indian Ocean, picoplankton can contribute 60-90\% to total Chl $a$ (Maranon et al. 2001; Not et al. 2008). Even though the majority of the picoplankton in these areas is composed by cyanobacteria, picoeukaryotes can contribute up to $54 \%$ to total $\mathrm{Chl}$ $a$ (Not et al. 2008). In contrast to these data, we found a maximum picoeukaryotic (chlorophytes) contribution to total Chl $a$ of only $18 \%$. We observed that south of the PF, the contribution of picoeukaryotes was very low. Diez et al. (2004) found out that south of the PF, cells $<5 \mu \mathrm{m}$ can contribute up to $80 \%$ to total Chl $a$. The Subantarctic and polar open waters, investigated here, were dominated by nano- and microeukaryotes. These findings are in agreement with other observations of microeukaryotes dominating in ACC waters (Hewes 2009), especially south of the PF (Landry et al. 2001). The low water temperatures can be rejected as explanation for the low abundance of picoeukaryotes, because Tremblay et al. (2009) have described a picophytoplankton contribution to total phytoplankton abundance of $76 \%$ in the Canadian High Arctic. One difference between the Canadian High Arctic and the Southern Ocean is the more coastal character of the Arctic with much more freshwater input. In coastal Arctic waters, mamiellophytes, members of the prasinophytes, often dominate the picoplankton assemblage (Not et al. 2004). Mamiellophytes are always present and often very abundant in the Arctic (Lovejoy et al. 2006, 2007). Other factors than temperature, such as salinity, nutrient availability, competition, grazing, or mixing of the surface layer, may account for the low contribution of picoeukaryotes we found in the Southern Ocean.

We applied molecular tools to gain a deeper insight into the protistan community structure and composition and to overcome the limitation on autotrophs of the pigment analysis. The ARISA and 454-pyrosequencing analyses revealed similar patterns as the pigment analysis. The SAF and PF separate three distinctive communities. Diez et al. (2004) also did a fingerprint analysis (DGGE) of eukaryotic picoplankton assemblages across the main fronts in the Southern Ocean. They found characteristic picoeukaryotic assemblages for each water mass in the Atlantic sector of the Southern Ocean and the SAF and PF constituted as separator, supporting our results. The ARISA approach is based on the presence/absence of fragments and do not distinguish between species/groups. However, we were able to distinguish between the communities in the three large-scale water masses, showing the applicability of the ARISA approach. This can be helpful for future studies, especially in areas with less clear separated water masses. Additionally, the low costs and time consumption provide the opportunity to investigate a large sample set. The 454-pyrosequencing approach, which is based on a higher resolution, confirmed the ARISA outcome.

We have shown that the combination of established techniques (HPLC) and new tools (ARISA, 454-pyrosequencing) serves as a good approach to characterize the structure of protistan assemblages in a large sample set spanning a huge geographical area. The combination of different techniques revealed different protist communities in different regions that were separated by oceanic fronts.

\section{Community composition}

We performed 454-pyrosequencing with six representative samples, based on ARISA and pigment analysis, to offset the limited taxonomical resolution of these methods. We found several strong indications for biogeographic distribution. The distribution of OTUs (Fig. 6) indicates that the SAZ and AZ represent distinct protistan assemblages. The PFZ, sharing most of the OTUs with the other two regions, serves as a transition zone.

We observed sequences belonging to the genus Emiliania only in the SAZ and PFZ. South of the PF, we detected no sequences appertaining to coccolithophores. Gravalosa et al. (2008) found out that the abundance of 
coccolithophores (mainly Emiliania huxleyi) in the eastern Amundsen Sea decreases polewards. They detected no coccolithophores south of $65.5^{\circ} \mathrm{S}$, confirming our findings. The Phaeocystis sp. 2 OTU, which was only occurring south of the SAF, is another example for biogeographic distribution. In the reference tree, this OTU was placed next to Phaeocystis jahnii, whereas the dominating Phaeocystis sp. 1 OTU, which also occurred north of the SAF, was placed near Phaeocystis antarctica. The occurrence of $P$. jahnii south of the PF is remarkable, because Zingone et al. (1999) described this species in the Mediterranean Sea, where very different environmental settings are found. Sequences most similar to $P$. jahnii have also been found in the Ross Sea by Gast et al. (2004). It seems that the genus Phaeocystis is more diverse than presumed, which Medlin and Zingone (2007) also illustrated by reviewing the genetic variation of 22 isolates. Furthermore, it is possible that Phaeocystis has different ecotypes that are able to cope with a wide range of environmental conditions.

In general, the sequence assemblages north of the SAF were dominated by dinoflagellates. The CHEMTAX data cannot confirm the dominance of dinoflagellates, because most dinoflagellates are heterotrophic (Sherr and Sherr 2007) and thus do not have pigments. It is not uncommon for dinoflagellates to occur in Antarctic waters (Kozlowski et al. 2011), but such a high contribution as we found was not observed so far. Dinoflagellates might be overrepresented in the sequence data, because of the high number of gene copies (also discussed later). However, most of the past studies used pigment-based analyses and thus might have missed most of the heterotrophic dinoflagellates. South of the SAF, sequences related to diatoms and haptophytes appear more important, which is backed up by the CHEMTAX data. The generally higher contribution of diatoms in the CHEMTAX data might be due to the rather unspecific marker pigment fucoxanthin in diatoms and the overrepresentation of dinoflagellates in the 454 data (gene copy number issue). The higher importance of diatoms is in agreement with the findings of Landry et al. (2001) and Alderkamp et al. (2010), who described an enhanced importance of larger cells and a greater contribution of diatoms south of the PF. Ning et al. (1996) also observed a dominance of diatoms in cold Antarctic waters and dinoflagellates dominating in the warmer waters north of the SAF. One reason for this change in community composition is the nutrient limitation, especially silicon, north of the SAF (Ning et al. 1996). The abundant diatom phylotypes we found belong to genera (Chaetoceros, Corethron, Pseudo-nitzschia, Thalassionema, and Thalassiosira) which were reported previously in open waters between Australia and Antarctica and in the Ross Sea (Ishikawa et al. 2002; Gast et al. 2004;
Kopczynska et al. 2007). The genus Actinocyclus was also previously reported in Antarctic waters, but in coastal regions like the Antarctic Peninsula (Olguin and Alder 2011). Finding comparative distribution data for dinoflagellates and labyrinthulids is practically impossible, as most of the abundant phylotypes identified in our samples shared most sequence identity with unclassified representatives. The limited occurrence of chlorophytes, which were only among the abundant phylotypes north of the SAF, is congruent to the distribution derived from HPLC.

The most dominant phylotype south of the PF belongs to the genus Phaeocystis. Our observation is supported by other studies (Elsayed et al. 1983; DiTullio et al. 2000), which revealed huge blooms of Phaeocystis in the Ross Sea. It seems that Phaeocystis cope best with the environmental conditions in the open ocean waters south of the PF, which are characterized by low temperatures and upwelling of nutrient-rich deep water (Talley et al. 2011). Grazing pressure may also explain the high abundance of Phaeocystis. Tang et al. (2008) demonstrated that Phaeocystis increases the size of its colonies in the presence of grazers. Caron et al. (2000) found no significant grazing at most of the stations they sampled, which were mostly dominated by Phaeocystis. In our samples, it might be that Phaeocystis escaped the grazing pressure and hence dominated the assemblage. However, we cannot conclude on the cell stage with our data set. Only three of the 36 abundant OTUs were abundant in all three regions (Phaeocystis sp. 1, unc. Dinoflagellate 1, and unc. Dinoflagellate 2), suggesting that only a few organisms are able to cope with the different environmental conditions.

The interpretation of molecular data requires the awareness of potential biases, which can lead to a tampering of the real situation. Primer specificity is one possible bias (Zhu et al. 2005; Stoeck et al. 2006). The amplification of the different species in an environmental sample can vary and the used primers might not capture some species. Zhu et al. (2005) also describe that the number of rRNA gene copies depends on the cell size and varies among eukaryotes from one to several thousands; especially, the dinoflagellates seem to have more rRNA gene copies than the other taxonomical groups and thus might be overrepresented in molecular data. For this reason, we decided against calculating diversity indices in our study. A prerequisite for diversity indices is the numeration of single organisms. The ARISA approach, which we have used for the first time for describing protistan assemblages (Wolf et al. 2013), can only serve as an overview of the community structure for the most dominant members of the assemblage, due to the qualitative character and the overlapping of fragment lengths 
among different species. The placement of sequences gained via 454-pyrosequencing has to be interpreted with care, because the length of only $\sim 500-600 \mathrm{bp}$ is decreasing the robustness of the phylogenetic annotation.

In conclusion, we have shown that distinct protist community assemblages characterize different large-scale water masses in the studied area of the Southern Ocean. The most prominent separator was the PF. Dinoflagellates and smaller cells, like labyrinthulids and Syndiniales, were dominating north of the PF, whereas haptophytes and diatoms became more important south of the PF. We also showed that the ARISA approach is a valuable method for investigating the structure of protistan assemblages in large sample sets, which are needed for assessments of biogeographical differences in microbial communities. This study serves as a baseline for the assessment of future changes of protist assemblages due to climate change. Smaller cells might become more important in marine ecosystems in the future, due to warming surface water temperatures, as expected by several authors (Daufresne et al. 2009; Li et al. 2009). Warmer surface water temperatures promote stratification and nutrient depletion. Small cells have a large surface-area-to-volume ratio that provides effective acquisition of nutrient solutes and photons, as well as hydrodynamic resistance to sinking ( $\mathrm{Li}$ et al. 2009). This would change food webs and biogeochemical cycles in the Southern Ocean, because so far, in this area small cells (picoplankton) are less abundant, which we have also observed in this study.

Acknowledgments This study was accomplished within the Young Investigator Group PLANKTOSENS (VH-NG-500), funded by the Initiative and Networking Fund of the Helmholtz Association. We thank the captain and crew of the RV Polarstern for their support during the cruise. We are grateful to F. Kilpert and B. Beszteri for their bioinformatical support. We also want to thank A. Schroer, A. Nicolaus, and K. Oetjen for technical support in the laboratory and Steven Holland for providing access to the program Analytic Rarefaction 1.3. We would like to acknowledge E. M. Nöthig and K. Kohls for their insightful discussions and reviews of this manuscript.

\section{References}

Alderkamp AC, de Baar HJW, Visser RJW, Arrigo KR (2010) Can photoinhibition control phytoplankton abundance in deeply mixed water columns of the Southern Ocean? Limnol Oceanogr 55:1248-1264

Azam F, Malfatti F (2007) Microbial structuring of marine ecosystems. Nat Rev Microbiol 5:782-791. doi:10.1038/nrmicro1747

Baldwin AJ, Moss JA, Pakulski JD, Catala P, Joux F, Jeffrey WH (2005) Microbial diversity in a Pacific Ocean transect from the Arctic to Antarctic circles. Aquat Microb Ecol 41:91-102

Banse K (1996) Low seasonality of low concentrations of surface chlorophyll in the subantarctic water ring: underwater irradiance, iron, or grazing? Prog Oceanogr 37:241-291. doi:10.1016/ s0079-6611(96)00006-7

Barlow RG, Cummings DG, Gibb SW (1997) Improved resolution of mono- and divinyl chlorophylls $\mathrm{a}$ and $\mathrm{b}$ and zeaxanthin and lutein in phytoplankton extracts using reverse phase C-8 HPLC. Mar Ecol Prog Ser 161:303-307. doi:10.3354/meps161303

Behnke A, Engel M, Christen R, Nebel M, Klein RR, Stoeck T (2011) Depicting more accurate pictures of protistan community complexity using pyrosequencing of hypervariable SSU rRNA gene regions. Environ Microbiol 13:340-349. doi:10.1111/j. 1462-2920.2010.02332.x

Bent SJ, Forney LJ (2008) The tragedy of the uncommon: understanding limitations in the analysis of microbial diversity. ISME J 2:689-695. doi:10.1038/ismej.2008.44

Bidigare RR (1991) Analysis of algal chlorophylls and carotenoids. In: Hurd DC, Spencer DW (eds) Marine particles: analysis and characterisation. American Geophysical Union, Washington, DC. Geophys Monogr Ser 63:119-123. doi:10.1029/ GM063p0119

Boyd PW (2002) Environmental factors controlling phytoplankton processes in the Southern Ocean. J Phycol 38:844-861

Caron DA, Dennett MR, Lonsdale DJ, Moran DM, Shalapyonok L (2000) Microzooplankton herbivory in the Ross Sea, Antarctica. Deep Sea Res Part II Top Stud Oceanogr 47:3249-3272

Chang FH, Williams MJM, Schwarz JN, Hall JA, Maas EW, Stewart R (2013) Spatial variation of phytoplankton assemblages and biomass in the New Zealand sector of the Southern Ocean during the late austral summer 2008. Polar Biol 36:391-408

Comeau AM, Benoît P, Thaler M, Gosselin M, Poulin M, Lovejoy C (2013) Protists in Arctic drift and land-fast sea ice. J Phycol 49:229-240

Danovaro R, Corinaldesi C, Luna GM, Magagnini M, Manini E, Pusceddu A (2009) Prokaryote diversity and viral production in deep-sea sediments and seamounts. Deep Sea Res Part II Top Stud Oceanogr 56:738-747. doi:10.1016/j.dsr2.2008.10.011

Daufresne M, Lengfellner K, Sommer U (2009) Global warming benefits the small in aquatic ecosystems. Proc Natl Acad Sci USA 106:12788-12793. doi:10.1073/pnas.0902080106

Davidson AT, Scott FJ, Nash GV, Wright SW, Raymond B (2010) Physical and biological control of protistan community composition, distribution and abundance in the seasonal ice zone of the Southern Ocean between 30 and 80 degrees E. Deep Sea Res Part II Top Stud Oceanogr 57:828-848. doi:10.1016/j.dsr2.2009. 02.011

Debaar HJW, Dejong JTM, Bakker DCE, Loscher BM, Veth C, Bathmann U, Smetacek V (1995) Importance of iron for plankton blooms and carbon-dioxide drawdown in the Southern Ocean. Nature 373:412-415

Detmer AE, Bathmann UV (1997) Distribution patterns of autotrophic pico- and nanoplankton and their relative contribution to algal biomass during spring in the Atlantic sector of the Southern Ocean. Deep Sea Res Part II Top Stud Oceanogr 44:299-320

Diez B, Pedros-Alio C, Massana R (2001) Study of genetic diversity of eukaryotic picoplankton in different oceanic regions by smallsubunit rRNA gene cloning and sequencing. Appl Environ Microbiol 67:2932-2941

Diez B, Massana R, Estrada M, Pedros-Alio C (2004) Distribution of eukaryotic picoplankton assemblages across hydrographic fronts in the Southern Ocean, studied by denaturing gradient gel electrophoresis. Limnol Oceanogr 49:1022-1034

DiTullio GR, Grebmeier JM, Arrigo KR, Lizotte MP, Robinson DH, Leventer A, Barry JB, VanWoert ML, Dunbar RB (2000) Rapid and early export of Phaeocystis antarctica blooms in the Ross Sea, Antarctica. Nature 404:595-598. doi:10.1038/35007061

Dray S, Dufour AB (2007) The ade4 package: implementing the duality diagram for ecologists. J Stat Softw 22:1-20 
Eddy SR (2011) Accelerated profile HMM searches. PLoS Comput Biol 7:e1002195. doi:10.1371/journal.pcbi.1002195

Edgar RC, Haas BJ, Clemente JC, Quince C, Knight R (2011) UCHIME improves sensitivity and speed of chimera detection. Bioinformatics 27:2194-2200. doi:10.1093/bioinformatics/btr381

Edvardsen B, Eikrem W, Throndsen J, Sez AG, Probert I, Medlin LK (2011) Ribosomal DNA phylogenies and a morphological revision provide the basis for a revised taxonomy of the Prymnesiales (Haptophyta). Eur J Phycol 46:202-228. doi:10. 1080/09670262.2011.594095

Elsayed SZ, Biggs DC, Holmhansen O (1983) Phytoplankton standing crop, primary productivity and near-surface nitrogenous nutrient fields in the Ross Sea, Antarctica. Deep Sea Res Part A Oceanogr Res Pap 30:871-886. doi:10.1016/0198-0149(83)90005-5

Elwood HJ, Olsen GJ, Sogin ML (1985) The small-subunit ribosomal RNA gene sequences from the hypotrichous ciliates Oxytricha nova and Stylonychia pustulata. Mol Biol Evol 2:399-410

Galand PE, Casamayor EO, Kirchman DL, Lovejoy C (2009) Ecology of the rare microbial biosphere of the Arctic Ocean. Proc Natl Acad Sci USA 106:22427-22432. doi:10.1073/pnas. 0908284106

Gaspar JM, Thomas WK (2013) Assessing the consequences of denoising marker-based metagenomic data. PLoS ONE 8:e60458. doi:10.1371/journal.pone.0060458

Gast RJ, Dennett MR, Caron DA (2004) Characterization of protistan assemblages in the Ross Sea, Antarctica, by denaturing gradient gel electrophoresis. Appl Environ Microbiol 70:2028-2037. doi:10.1128/aem.70.4.2028- 2037.2004

Gravalosa JM, Flores JA, Sierro FJ, Gersonde R (2008) Sea surface distribution of coccolithophores in the eastern Pacific sector of the Southern Ocean (Bellingshausen and Amundsen Seas) during the late austral summer of 2001. Mar Micropaleontol 69:16-25. doi:10.1016/j.marmicro.2007.11.006

Guillou L, Eikrem W, Chrétiennot-Dinet MJ, Le Gall F, Massana R, Romari K, Pedrós-Alió C, Vaulot D (2004) Diversity of picoplanktonic prasinophytes assessed by direct nuclear SSU rDNA sequencing of environmental samples and novel isolates retrieved from oceanic and coastal marine ecosystems. Protist 155:193-214

Hamilton AK, Lovejoy C, Galand PE, Ingram RG (2008) Water masses and biogeography of picoeukaryote assemblages in a cold hydrographically complex system. Limnol Oceanogr 53:922-935

Hewes CD (2009) Cell size of Antarctic phytoplankton as a biogeochemical condition. Antarct Sci 21:457-470. doi:10. 1017/s0954102009990125

Ishikawa A, Wright SW, van den Enden RL, Davidson AT, Marchant HJ (2002) Abundance, size structure and community composition of phytoplankton in the Southern Ocean in the austral summer 1999/2000. Polar Biosci 15:11-26

Jeffrey SW, Mantoura RFC, Bjornland T (1997) Data for the identification of 47 key phytoplankton pigments. In: Jeffrey SW et al (eds) Phytoplankton pigments in oceanography: Guideline to modern methods. UNESCO Publishing, Paris. Monogr Oceanogr Methodol 10:449-559

Kopczynska EE, Savoye N, Dehairs F, Cardinal D, Elskens M (2007) Spring phytoplankton assemblages in the Southern Ocean between Australia and Antarctica. Polar Biol 31:77-88. doi:10. 1007/s00300-007-0335-6

Kozlowski WA, Deutschman D, Garibotti I, Trees C, Vernet M (2011) An evaluation of the application of CHEMTAX to Antarctic coastal pigment data. Deep Sea Res Part I Oceanogr Res Pap 58:350-364. doi:10.1016/j.dsr.2011.01.008

Kunin V, Engelbrektson A, Ochman H, Hugenholtz P (2010) Wrinkles in the rare biosphere: pyrosequencing errors can lead to artificial inflation of diversity estimates. Environ Microbiol 12:118-123. doi:10.1111/j.1462-2920.2009.02051.x

Landry MR, Brown SL, Selph KE, Abbott MR, Letelier RM, Christensen S, Bidigare RR, Casciotti K (2001) Initiation of the spring phytoplankton increase in the Antarctic Polar Front Zone at 170 degrees W. J Geophys Res Oceans 106:13903-13915. doi:10.1029/1999jc000187

Li WKW, McLaughlin FA, Lovejoy C, Carmack EC (2009) Smallest algae thrive as the Arctic Ocean freshens. Science 326:539. doi:10.1126/science. 1179798

Lopez-Garcia P, Rodriguez-Valera F, Pedros-Alio C, Moreira D (2001) Unexpected diversity of small eukaryotes in deep-sea Antarctic plankton. Nature 409:603-607

Lovejoy C, Potvin M (2011) Microbial eukaryotic distribution in a dynamic Beaufort Sea and the Arctic Ocean. J Plankton Res 33:431-444. doi:10.1093/plankt/fbq124

Lovejoy C, Massana R, Pedros-Alio C (2006) Diversity and distribution of marine microbial eukaryotes in the Arctic Ocean and adjacent seas. Appl Environ Microbiol 72:3085-3095

Lovejoy C, Vincent WF, Bonilla S, Roy S, Martineau MJ, Terrado R, Potvin M, Massana R, Pedros-Alio C (2007) Distribution, phylogeny, and growth of cold-adapted picoprasinophytes in Arctic seas. J Phycol 43:78-89

Maranon E, Holligan PM, Barciela R, Gonzalez N, Mourino B, Pazo MJ, Varela M (2001) Patterns of phytoplankton size structure and productivity in contrasting open-ocean environments. Mar Ecol Prog Ser 216:43-56. doi:10.3354/meps216043

Margulies M, Egholm M, Altman WE, Attiya S, Bader JS, Bemben LA, Berka J, Braverman MS, Chen YJ, Chen ZT, Dewell SB, Du L, Fierro JM, Gomes XV, Godwin BC, He W, Helgesen S, Ho $\mathrm{CH}$, Irzyk GP, Jando SC, Alenquer MLI, Jarvie TP, Jirage KB, Kim JB, Knight JR, Lanza JR, Leamon JH, Lefkowitz SM, Lei M, Li J, Lohman KL, Lu H, Makhijani VB, McDade KE, McKenna MP, Myers EW, Nickerson E, Nobile JR, Plant R, Puc BP, Ronan MT, Roth GT, Sarkis GJ, Simons JF, Simpson JW, Srinivasan M, Tartaro KR, Tomasz A, Vogt KA, Volkmer GA, Wang SH, Wang Y, Weiner MP, Yu PG, Begley RF, Rothberg JM (2005) Genome sequencing in microfabricated high-density picolitre reactors. Nature 437:376-380. doi:10.1038/nature03959

Martin JH, Gordon RM, Fitzwater SE (1990) Iron in Antarctic waters. Nature 345:156-158. doi:10.1038/345156a0

Matsen FA, Kodner RB, Armbrust EV (2010) pplacer: linear time maximum-likelihood and Bayesian phylogenetic placement of sequences onto a fixed reference tree. BMC Bioinformatics 11:538. doi:10.1186/1471-2105-11-538

Medlin L, Zingone A (2007) A taxonomic review of the genus Phaeocystis. Biogeochemistry 83:3-18. doi:10.1007/s10533007-9087-1

Medlin L, Elwood HJ, Stickel S, Sogin ML (1988) The characterization of enzymatically amplified eukaryotic 16 s-like rRNAcoding regions. Gene 71:491-499

Miranda LN, Zhuang YY, Zhang H, Lin S (2012) Phylogenetic analysis guided by intragenomic SSU rDNA polymorphism refines classification of "Alexandrium tamarense" species complex. Harmful Algae 16:35-48. doi:10.1016/j.hal.2012.01.002

Nickrent DL, Sargent ML (1991) An overview of the secondary structure of the V4-region of eukaryotic small-subunit ribosomal-RNA. Nucleic Acids Res 19:227-235. doi:10.1093/nar/ 19.2.227

Ning XR, Lin ZL, Zhu GH, Shi JX (1996) Size-fractionated biomass and productivity of phytoplankton and particulate organic carbon in the Southern Ocean. Polar Biol 16:1-11

Not F, Latasa M, Marie D, Cariou T, Vaulot D, Simon N (2004) A single species, Micromonas pusilla (Prasinophyceae), dominates the eukaryotic picoplankton in the western English channel. 
Appl Environ Microbiol 70:4064-4072. doi:10.1128/aem.70.7. 4064-4072.2004

Not F, Latasa M, Scharek R, Viprey M, Karleskind P, Balague V, Ontoria-Oviedo I, Cumino A, Goetze E, Vaulot D, Massana R (2008) Protistan assemblages across the Indian Ocean, with a specific emphasis on the picoeukaryotes. Deep Sea Res Part I Oceanogr Res Pap 55:1456-1473. doi:10.1016/j.dsr.2008.06. 007

Oksanen J, Blanchet FG, Kindt R, Legendre P, Minchin PR, O'Hara RB, Simpson GL, Solymos P, Stevens MHH, Wagner H (2012) vegan: community ecology package. $\mathrm{R}$ package version 2.0-4. http://CRAN.R-project.org/package=vegan

Olguin HF, Alder VA (2011) Species composition and biogeography of diatoms in Antarctic and Subantarctic (Argentine shelf) waters (37-76 degrees S). Deep Sea Res Part II Top Stud Oceanogr 58:139-152. doi:10.1016/j.dsr2.2010.09.031

Orr JC, Fabry VJ, Aumont O, Bopp L, Doney SC, Feely RA, Gnanadesikan A, Gruber N, Ishida A, Joos F, Key RM, Lindsay K, Maier-Reimer E, Matear R, Monfray P, Mouchet A, Najjar RG, Plattner GK, Rodgers KB, Sabine CL, Sarmiento JL, Schlitzer R, Slater RD, Totterdell IJ, Weirig MF, Yamanaka Y, Yool A (2005) Anthropogenic ocean acidification over the twenty-first century and its impact on calcifying organisms. Nature 437:681-686. doi:10.1038/nature04095

Orsi AH, Whitworth T, Nowlin WD (1995) On the meridional extent and fronts of the Antarctic circumpolar current. Deep Sea Res Part I Oceanogr Res Pap 42:641-673. doi:10.1016/09670637(95)00021-w

Pedros-Alio C (2006) Marine microbial diversity: can it be determined? Trends Microbiol 14:257-263

Peeken I (1997) Photosynthetic pigment fingerprints as indicators of phytoplankton biomass and development in different water masses of the Southern Ocean during austral spring. Deep Sea Res Part II Top Stud Oceanogr 44:261-282. doi:10.1016/s09670645(96)00077-x

Pollard RT, Lucas MI, Read JF (2002) Physical controls on biogeochemical zonation in the Southern Ocean. Deep Sea Res Part II Top Stud Oceanogr 49:3289-3305. doi:10.1016/s09670645(02)00084-x

Priddle J, Smetacek V, Bathmann U (1992) Antarctic marine primary production, biogeochemical carbon cycles and climate-change. Philos Trans R Soc Lond Ser B Biol Sci 338:289-297. doi:10. 1098/rstb 1992.0149

R Development Core Team (2008) R: a language and environment for statistical computing. R Foundation for Statistical Computing, Vienna

Ramette A (2009) Quantitative community fingerprinting methods for estimating the abundance of operational taxonomic units in natural microbial communities. Appl Environ Microbiol 75:2495-2505. doi:10.1128/aem.02409-08

Schlüter L, Henriksen P, Nielsen TG, Jakobsen HH (2011) Phytoplankton composition and biomass across the southern Indian Ocean. Deep Sea Res Part I Oceanogr Res Pap 58:546-556. doi:10.1016/j.dsr.2011.02.007

Sherr EB, Sherr BF (2007) Heterotrophic dinoflagellates: a significant component of microzooplankton biomass and major grazers of diatoms in the sea. Mar Ecol Prog Ser 352:187-197

Smith JL, Barrett JE, Tusnady G, Rejto L, Cary SC (2010) Resolving environmental drivers of microbial community structure in
Antarctic soils. Antarct Sci 22:673-680. doi:10.1017/ s0954102010000763

Sogin ML, Morrison HG, Huber JA, Mark Welch D, Huse SM, Neal PR, Arrieta JM, Herndl GJ (2006) Microbial diversity in the deep sea and the underexplored "rare biosphere". Proc Natl Acad Sci USA 103:12115-12120. doi:10.1073/pnas.0605127103

Stoeck T, Hayward B, Taylor GT, Varela R, Epstein SS (2006) A Multiple PCR-primer approach to access the microeukaryotic diversity in environmental samples. Protist 157:31-43

Stoeck T, Bass D, Nebel M, Christen R, Jones MDM, Breiner HW, Richards TA (2010) Multiple marker parallel tag environmental DNA sequencing reveals a highly complex eukaryotic community in marine anoxic water. Mol Ecol 19:21-31. doi:10.1111/j. 1365-294X.2009.04480.x

Talley LD, Pickard GL, Emery WJ, Swift JH (2011) Descriptive physical oceanography—an introduction. Elsevier, Boston

Tang KW, Smith WO, Elliott DT, Shields AR (2008) Colony size of Phaeocystis antarctica (Prymnesiophyceae) as influenced by zooplankton grazers. J Phycol 44:1372-1378

Tortell PD, Payne CD, Li YY, Trimborn S, Rost B, Smith WO, Riesselman C, Dunbar RB, Sedwick P, DiTullio GR (2008) CO2 sensitivity of Southern Ocean phytoplankton. Geophys Res Lett 35:L04605. doi:10.1029/2007g1032583

Tremblay G, Belzile C, Gosselin M, Poulin M, Roy S, Tremblay JE (2009) Late summer phytoplankton distribution along a $3500 \mathrm{~km}$ transect in Canadian Arctic waters: strong numerical dominance by picoeukaryotes. Aquat Microb Ecol 54:55-70. doi:10.3354/ ame 01257

White TJ, Bruns T, Lee S, Taylor JW (1990) Amplification and direct sequencing of fungal ribosomal RNA genes for phylogenetics. In: Innis MA, Gelfand DH, Sninsky JJ, White TJ (eds) PCR protocols: a guide to methods and applications. Academic Press, New York, pp 315-322

Wolf C, Frickenhaus S, Kilias ES, Peeken I, Metfies K (2013) Regional variability in eukaryotic protist communities in the Amundsen Sea. Antarc Sci 25:741-751. doi:10.1017/S09541020 13000229

Wright SW, Ishikawa A, Marchant HJ, Davidson AT, van den Enden RL, Nash GV (2009) Composition and significance of picophytoplankton in Antarctic waters. Polar Biol 32:797-808

Wright SW, Van Den Enden RL, Pearce I, Davidson AT, Scott FJ, Westwood KJ (2010) Phytoplankton community structure and stocks in the Southern Ocean (30-80 degrees E) determined by CHEMTAX analysis of HPLC pigment signatures. Deep Sea Res Part II 57:758-778

Wulff A, Wangberg SA (2004) Spatial and vertical distribution of phytoplankton pigments in the eastern Atlantic sector of the Southern Ocean. Deep Sea Res Part II Top Stud Oceanogr 51:2701-2713. doi:10.1016/j.dsr2.2001.01.002

Zhu F, Massana R, Not F, Marie D, Vaulot D (2005) Mapping of picoeucaryotes in marine ecosystems with quantitative PCR of the 18S rRNA gene. FEMS Microbiol Ecol 52:79-92. doi:10. 1016/j.femsec.2004.10.006

Zingone A, Chrétiennot-Dinet MJ, Lange M, Medlin L (1999) Morphological and genetic characterization of Phaeocystis cordata and P-jahnii (Prymnesiophyceae), two new species from the Mediterranean Sea. J Phycol 35:1322-1337. doi:10. 1046/j.1529-8817.1999.3561322 